\title{
Artificial feeding of Ornithodoros fonsecai (Acari: Argasidae) with the anticoagulant Alsever
}

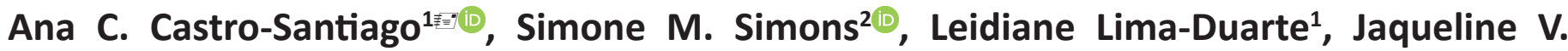 \\ Camargo $^{3(\infty}$, Rosangela Z. Machado ${ }^{3(\infty}$, Marcos R. André ${ }^{3(}$, Darci M. Barros-Battesti ${ }^{1,3}$
}

${ }^{1}$ Department of Preventive Veterinary Medicine and Animal Health, Faculty of Veterinary Medicine and Animal Science, University of São Paulo, SP, Brazil. 2Parasitology Laboratory, Instituto Butantan, São Paulo, SP, Brazil. ${ }^{3}$ Department of Pathology, Reproduction and One Health, Faculty of Agrarian and Veterinary Sciences, UNESP, Jaboticabal, SP, Brazil.

拝- Corresponding author: ana_carolinacsantiago@hotmail.com

Edited by: Ricardo Bassini (Guest Editor)

Received: November 05, 2021. Accepted: November 21, 2021. Published: December 09, 2021.

Abstract. Ornithodoros fonsecai is a species of argasid tick endemic to Brazil, described in the "São Miguel" cave located in the municipality of Bonito, state of Mato Grosso do Sul, central-western region of Brazil. The artificial feeding technique makes it possible to study the biology of hematophagous arthropods using artificial or natural membranes, as well as different types of blood and anticoagulants. Thus, the aim of the present study was to feed artificially $O$. fonsecai second instar (N2) nymphs with rabbit blood using parafilm membrane and the anticoagulant Alsever. Ninety percent of the total N2 nymphs engorged and molted to N3 nymphs between 27 and 30 days after feeding, indicating that the use of this anticoagulant is efficient for artificially feeding $O$. fonsecai $\mathrm{N} 2$ nymphs under laboratory conditions.

Keywords: argasid tick, artificial feeding, anticoagulant, biology.

The argasid fauna is composed of five genera: Antricola, Argas, Nothoaspis, Otobius and Ornithodoros. Among the more than 200 species known worldwide, about 90 species occur in the Neotropical region (Caribbean, Southern Mexico and South America), and 20 species are currently known in Brazil (Muñoz-Leal et al. 2019; 2020; 2021). Argasids can live in different environments such as burrows, holes, bird nests, rock crevices, loose soils, tree bark and caves, parasitizing different host species. In addition, they can be found close to humans and domestic animals, inhabiting basements, roofs, stables, chicken coops, and rustic beds. They are abundant in arid and semiarid environments (Aragão 1936; Vial 2009; Brites-Neto et al. 2015), but some species are found parasitizing amphibians in very humid places (Barros-Battesti et al. 2015; Muñoz -Leal et al. 2017). In general, the life cycle of argasid ticks consists of four distinct stages: eggs, larvae, one to nine nymphal instars and adults (Vial 2009). Females can lay several batches of eggs (gonotrophic cycles), each one usually preceded by a blood meal, and sometimes by a new mating (Hoogstraal 1985; Vial 2009; Landulfo et al. 2012; Ramirez et al. 2016).

Among the argasid ticks, the genus Ornithodoros is the most diverse with more than 130 described species in the world (Labruna \& Venzal 2009; Barros-Battesti et al. 2015; Muñoz-Leal et al. 2017; Sun et al. 2019). Sixty-one of them occur in the Neotropical region (Venzal et al. 2019) and of these, 20 are distributed in Brazil, namely Ornithodoros brasiliensis Aragão, 1923; Ornithodoros capensis Neumann, 1901; Ornithodoros cavernicolous Dantas-Torres, Venzal \& Labruna, 2012; Ornithodoros cerradoensis Muñoz-Leal, Martins \& Labruna, 2020; Ornithodoros faccinii Barros-Battesti, Landulfo \& Luz, 2015; Ornithodoros fonsecai (Labruna \& Venzal, 2009); Ornithodoros guaporensis Nava, Venzal \& Labruna, 2013; Ornithodoros hasei (Schulze, 1935); Ornithodoros kohlsi Guglielmone \& Keirans, 2002; Ornithodoros marinkellei Kohls, Clifford \& Jones, 1969; Ornithodoros mimon Kohls, Clifford \& Jones, 1969; Ornithodoros peropteryx Kohls, Clifford \& Jones, 1969; Ornithodoros rietcorreai Labruna, Nava \& Venzal, 2016; Ornithodoros rondoniensis Labruna, Terrassini, Camargo, Brandão, Ribeiro \& Estrada-Peña, 2008; Ornithodoros rostratus Aragão, 1911; Ornithodoros rudis Karsh, 1880; Ornithodoros saraivai Muñoz-Leal \&
Labruna, 2017; Ornithodoros setosus Kohls, Clifford \& Jones, 1969, Ornithodoros stageri Cooley \& Kohls, 1941 and Ornithodoros tabajara Muñoz-Leal \& Labruna, 2021 (Dantas-Torres et al. 2019; Muñoz-Leal et al. 2020; 2021). Recently, three species of the genus Ornithodoros were excluded from the list of Brazilian tick fauna: Ornithodoros jul Schulze, 1940, Ornithodoros nattereri Warburton, 1927 and Ornithodoros talaje (Guérin-Méneville, 1849). The first two species are only known from their original descriptions, and it is not known where the types are located, while current evidence strongly indicates that $O$. talaje does not occur in Brazil. Thus, this species was also excluded (Dantas-Torres et al. 2019).

Ornithodoros fonsecai is an argasid tick that parasitizes mammals of the order Chiroptera. Its description was based on the morphological features of larvae collected from Peropteryx macrotis Wagner, 1843 and Desmodus rotundus E. Geoffroy, 1810, and from adults collected from crevices and walls of the "São Miguel" cave. in the municipality of Bonito, state of Mato Grosso do Sul, inhabited by these hosts (Labruna \& Venzal 2009). Larvae, nymphs and adults of this species were later found in the Gruta da Lagoa Azul State Park, Nobres, Mato Grosso state (Barros-Battesti et al. 2012). Luz et al. (2016) recorded the occurrence of larvae of this tick parasitizing bats of the species Carollia perspicillata Linnaeus, 1758 and Trachops cirrhosus Spix, 1823 in the Serra das Almas Nature Reserve (RPPN), municipality of Crateús, state of Ceará. Researchers who were in the cave in Nobres showed intense inflammatory lesions at the site of the bite, similar to those reported by Labruna \& Venzal (2009). This species belongs to the subgenus Alectorobius, which parasitizes bats. Molecularly, O. fonsecai is closely related to Ornithodoros dyeri Cooley \& Kohls, 1940 and O. rietcorreai (Muñoz-Leal et al. 2017). Morphologically, O. fonsecai larvae resemble the larvae of Ornithodoros peruvianus Kohls, Clifford \& Jones, 1969 and O. pteropterix (Labruna \& Venzal, 2009). The role of these tick species in the transmission of pathogens is unknown. However, some species of Ornithodoros (Alectorobius) from the neotropical region, such as $O$. talaje and Ornithodoros puertoricensis Fox, 1947, have already been associated with the transmission of recurrent fever and African swine fever in South America and Africa, respectively (Hoogstraal 1985 ; 
Labruna \& Venzal 2009). Although the role of $O$. fonsecai as a vector of pathogens is unknown, this possibility cannot be ruled out since it is an aggressive species to humans, and investigations on the presence of pathogens in these ticks have not yet been carried out.

Different artificial feeding techniques (or in vitro feeding) have been applied in the laboratory to a wide range of hematophagous arthropods. These techniques using artificial membranes offer relative simplicity and the potential to reduce or avoid the use of animals (e.g. guinea pigs). Some of these techniques have already been tested under laboratory conditions using membranes and capillary tubes to feed different species of argasid ticks, such as Ornithodoros savignyi Audouin, 1827, Ornithodoros moubata Murray, 1877, Ornithodoros coriacius Koch, 1844, Ornithodoros tholozani (Laboulbene \& Megnin, 1882), and Ornithodoros turicata Dugés, 1876 (Tarshis 1958; Mango \& Galun 1977; Hokama et al. 1987; Schwan et al. 1991; Ben-Yakir \& Galun 1993; Kim et al. 2017).

There are few studies conducted with ixodid and argasid ticks using this sort of artificial feeding using the anticoagulant lytic heparin (Schwan et al. 1991; Waladde et al. 1993). Additionally, tests have been carried out in the Parasitology Laboratory at the Butantan Institute, São Paulo, SP, using ethylenediamine-tetracetate (EDTA), 3.8\% sodium citrate, and lytic heparin as anticoagulants. While the latter has shown better results when it comes to survival of ticks artificially fed, the others showed to be lethal in the first days of feeding (unpublished results, personal communication with co-authors). Regarding the use of these techniques for artificial feeding of argasids, Schwan et al. (1991) found that there was no difference in the reproductive capacity of females of $O$. moubata when fed with heparinized and hemolyzed bovine blood (kept frozen) when compared to heparinized rat blood and defibrinated sheep blood.

In the present study, the anticoagulant Alsever was tested for feeding $O$. fonsecai nymphs. This anticoagulant is a solution prepared with $20.5 \mathrm{~g}$ of glucose, $8 \mathrm{~g}$ of sodium citrate, $4.2 \mathrm{~g}$ of sodium chloride, distilled water q.s.p. $1000 \mathrm{~mL}$. For this purpose, the biological parameters of artificially fed second instar nymphs (N2) of $O$. fonsecai from a laboratory colony maintained at the Laboratory of Immunoparasitology, Department of Pathology, Reproduction and One Health, São Paulo State University (UNESP), Jaboticabal, SP, was assessed.

In a $20 \mathrm{~mL}$ syringe containing $10 \mathrm{~mL}$ of Alsever anticoagulant, $10 \mathrm{~mL}$ of whole blood was collected from a New Zealand rabbit (Oryctolagus cuniculus). To remove excess anticoagulant, the mixture was centrifuged after the collection of blood for 15 minutes at 3,600 RPM (Excelsa II 206-BL Centrifuge, Fanem), and then about $7 \mathrm{~mL}$ of the anticoagulant was discarded. The blood was inserted into a "pouch" measuring $12 \mathrm{~cm} \times 8 \mathrm{~cm}$ prepared manually using a plastic paraffin film with paper (Parafilm " $M$ ", Athena). Once closed, some blood was smeared on top of the bag to attract the ticks.

The system used for feeding was conditioned in a shaker (Slow Speed Rotomix Shaker, Thermolyne) at minimum speed, containing a magnetic stirrer with heating (model $752 \mathrm{~A}$, Fisatom). The temperature reached $50^{\circ} \mathrm{C}$ a few minutes before placing a Petri dish containing the feeding pouch. Ticks were placed over the feeding bag and contained in a plastic bottle to prevent escape (Fig. 1).

Out of 20 N2 fed artificially, 18 N2 of them became engorged. They were observed daily to verify the molting time and whether the specimens were alive. All nymphs survived and began to molt to N3 between 27 and 30 days after artificial feeding. These results corroborate Santiago et al. (2019) which elucidated three generations of $O$. fonsecai kept in the laboratory and observed the period of molting from N2 to N3 nymphs being between 30-31, 19-31 and 14-32 days in the $1 \mathrm{st}$, 2nd and 3rd generation, respectively.

Schwan et al. (1991) observed O. moubata nymphs and adults in an artificial feeding system using parafilm as a membrane and different types of diet and anticoagulant. The tested diets and anticoagulants used were heparinized and hemolyzed bovine blood, heparinized rat blood and defibrinated sheep blood. These authors demonstrated that specimens of $O$. moubata fed better with heparinized bovine blood and the mortality rate was less than $5 \%$ in fed females. Ben-Yakir \&
Galun (1993) compared the feeding behavior of $O$. tholozani and $O$. moubata using various diets, membranes and feeding conditions. One of these conditions was the addition of fresh rabbit ear wax to the membrane, which showed a positive correlation between the feeding rate and the attachment speed of ticks of both species. The addition of a stimulator to the feeding apparatus is an important factor, as it brings the simulation of tick feeding closer to the natural feeding on hosts. In the present study, the stimulator used was to spread blood over the feeding bag to attract $O$. fonsecai nymphs, and the anticoagulant Alsever did not cause any harm to the artificially fed specimens.

The results of the present study indicate that the use of rabbit blood with the anticoagulant Alsever is effective for feeding $O$. fonsecai nymphs under laboratory conditions.

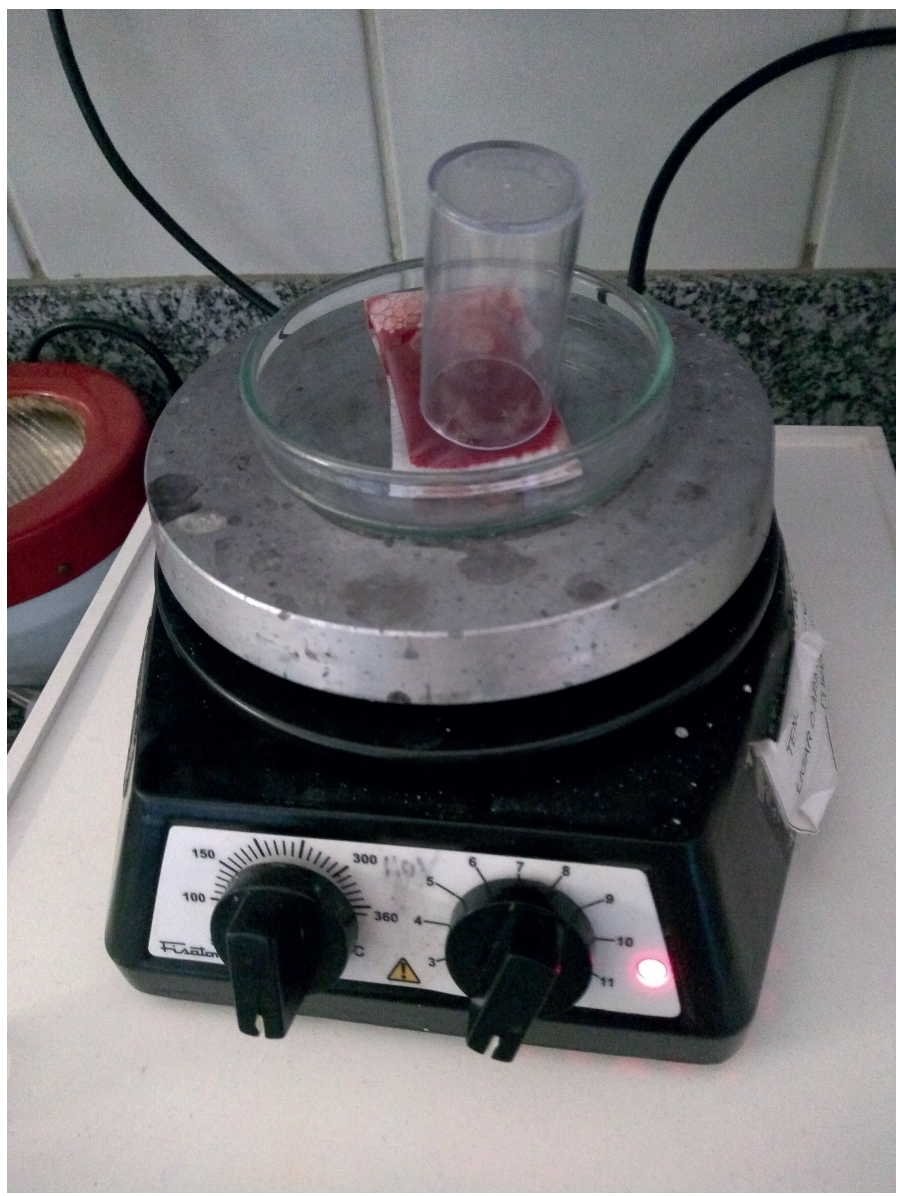

Figure 1. Artificial feeding system.

\section{Acknowledgments}

This work was supported by CNPq (National Council for Scientific and Technological Development) for the Productivity Grant to MRA and RZM. This study was also funded by the Coordination for the Improvement of Higher Education Personnel - Brazil (CAPES) - Financial Code 001.

\section{Authors' Contributions}

AC-SS, LL-D, JVC performed the experiment and observed all the procedures performed. SMS helped in the development of the technique for artificial feeding. RMZ, MRA and DMBB guided the studies carried out.

\section{References}

Aragão, H. D. B. (1936) Ixodidas brasileiros e de alguns paizes limitrophes. Memórias do Instituto Oswaldo Cruz, 31(4): 759-843.

Barros-Battesti, D. M.; Onofrio, V. C.; Nieri-Bastos, F. A.; Soares, J. F.; Marcili, A.; Famadas, K. M.; Faccini, J. L. H.; Ramirez, D. G.; Doyle, 
R. L.; Martins, J. R. et al. (2012) Ornithodoros brasiliensis Aragão (Acari: Argasidae): description of the larva, redescription of male and female, and neotype designation. Zootaxa, 3178(31): 22-32.

Barros-Battesti, D. M.; Landulfo, G. A.; Luz, H. R.; Marcili, A.; Onofrio, V. C.; Famadas, K. M. (2015) Ornithodoros faccinii n. sp. (Acari: Ixodida: Argasidae) parasitizing the frog Thoropa miliaris (Amphibia: Anura: Cycloramphidae) in Brazil. Parasites \& Vectors, 8(1): 268.

Ben-Yakir, D.; Galun, R. (1993) Comparative study of two argasid tick species: feeding response to phagostimulants. Israel Journal of Zoology, 39(2): 169-176.

Brites-Neto, J.; Duarte, K. M. R.; Martins, T. F. (2015) Tick-borne infections in human and animal population worldwide. Veterinary World, 8(3): 301.

Dantas-Torres, F.; Martins, T. F.; Muñoz-Leal, S.; Onofrio, V. C.; BarrosBattesti, D. M. (2019) Ticks (Ixodida: Argasidae, Ixodidae) of Brazil: updated species checklist and taxonomic keys. Ticks and Tick-borne Diseases, 10(6).

Hokama, Y.; Lane, R. S.; Howarth, J. A. (1987) Maintenance of adult and nymphal Ornithodoros coriaceus (Acari: Argasidae) by artificial feeding through a parafilm membrane. Journal of Medical Entomology, 24(3): 319-323.

Hoogstraal, H. (1985) Argasid and Nuttalliellid Ticks as Parasites and Vectors1. In Advances in parasitology, 24, 135-238.

Kim, H. J.; Filatov, S.; Lopez, J. E.; Pérez de León, A. A.; Teel, P. D. (2017) Blood feeding of Ornithodoros turicata larvae using an artificial membrane system. Medical and Veterinary Entomology, 31(2): 230-233.

Labruna, M. B.; Venzal, J. M. (2009) Carios fonsecai sp. nov. (Acari, Argasidae), a bat tick from the central-western region of Brazil. Acta Parasitologica, 54(4): 355-363.

Landulfo, G. A.; Pevidor, L. V.; dos Santos Sampaio, J.; Luz, H. R.; Onofrio, V. C.; Faccini, J. L. H.; Barros-Battesti, D. M. (2012) Life cycle of Ornithodoros mimon (Acari: Argasidae) under laboratory conditions. Experimental and Applied Acarology, 58(1): 69-80.

Luz, H. R.; Muñoz-Leal, S.; Almeida, J. C. D.; Faccini, J. L. H.; Labruna, M. B. (2016) Ticks parasitizing bats (Mammalia: Chiroptera) in the Caatinga Biome, Brazil. Revista Brasileira de Parasitologia Veterinária, 25(4): 484-491.

Mango, C. K.; Galun, R. (1977) Ornithodoros moubata: breeding in vitro. Experimental parasitology, 42(2): 282-288.

Muñoz-Leal, S.; Toledo, L. F.; Venzal, J. M.; Marcili, A.; Martins, T. F.; Acosta, I. C.; Pinter, A.; Labruna, M. B. (2017) Description of a new soft tick species (Acari: Argasidae: Ornithodoros) associated with stream-breeding frogs (Anura: Cycloramphidae: Cycloramphus) in Brazil. Ticks and Tick-Borne Diseases, 8(5): 682-692.

Muñoz-Leal, S.; Macedo, C.; Gonçalves, T. C.; Barreira, J. D.; Labruna, M. B.; de Lemos, E. R. S.; Ogrzewalska, M. (2019) Detected microorganisms and new geographic records of Ornithodoros rietcorreai (Acari: Argasidae) from northern Brazil. Ticks and Tickborne Diseases, 10(4): 853-861.

Muñoz-Leal, S.; Martins, M. M.; Nava, S.; Landulfo, G. A.; Simons, S. M.; Rodrigues, V. S.; Ramos, V. N.; Suzin, A.; Szabó, M. P. J.; Labruna, M. B. (2020) Ornithodoros cerradoensis n. sp. (Acari: Argasidae), a member of the Ornithodoros talaje (Guérin-Méneville, 1849) group, parasite of rodents in the Brazilian Savannah. Ticks and Tickborne Diseases, 11(5): 101497.

Muñoz-Leal, S.; Venzal, J. M.; Jorge, F. R.; Teixeira, B. M.; Labruna, M. B. (2021) A new species of soft tick from dry tropical forests of Brazilian Caatinga. Ticks and Tick-borne Diseases, 12(5): 101748.

Ramirez, D. G.; Landulfo, G. A.; Onofrio, V. C.; Simons, S. M.; Reck, J.; Martins, J. R.; Labruna, M. B.; Barros-Battesti, D. M. (2016) Laboratory life cycle of Ornithodoros brasiliensis (Acari: Argasidae): an endemic tick from southern Brazil. Ticks and Tick-Borne Diseases, 7(5): 730-733.

Santiago, A. C. C.; Duarte, L. L.; Martins, T. F.; Onofrio, V. C.; Nieri-Bastos, F. A.; de Campos Pacheco, R.; Melo, A. L. T.; Marcili, A.; BarrosBattesti, D. M. (2019). Occurrence of autogeny in a population of Ornithodoros fonsecai (Acari: Argasidae). Ticks and Tick-borne Diseases, 10(5): 1078-1084.
Schwan, E. V.; Hutton, D.; Shields, K. J. B.; Townson, S. (1991) Artificial feeding and successful reproduction in Ornithodoros moubata moubata (Murray, 1877) (Acarina: Argasidae). Experimental \& Applied Acarology, 13(2): 107-115.

Sun, Y.; Xu, R.; Liu, Z.; Wu, M.; Qin, T. (2019) Ornithodoros (Ornithodoros) huajianensis sp. nov. (Acari, argasidae), a new tick species from the Mongolian marmot (Marmota bobak sibirica), Gansu province in China. International Journal for Parasitology: Parasites and Wildlife, 9, 209-217.

Tarshis, I. B. (1958) A preliminary study on feeding Ornithodoros savignyi (Audouin) on human blood through animal-derived membranes (Acarina: Argasidae). Annals of the Entomological Society of America, 51(3): 294-299.

Venzal, J. M.; Castillo, G. N.; Gonzalez-Rivas, C. J.; Mangold, A. J.; Nava, S. (2019) Description of Ornithodoros montensis n. sp. (Acari, Ixodida: Argasidae), a parasite of the toad Rhinella arenarum (Amphibia, Anura: Bufonidae) in the Monte Desert of Argentina. Experimental and Applied Acarology, 78(1): 133-147.

Vial, L. (2009) Biological and ecological characteristics of soft ticks (Ixodida: Argasidae) and their impact for predicting tick and associated disease distribution. Parasite, 16(3): 191-202.

Waladde, S. M.; Young, A. S.; Mwaura, S. N.; Mwakima, F. N. (1993) Transmission of Theileria parva to cattle by Rhipicephalus appendiculatus adults fed as nymphae in vitro on infected blood through an artificial membrane. Parasitology, 107(3): 249-256. 